9

\title{
LAPORAN ETNOGRAFI (LADANG MISI) SEBAGAI SUMBER PENULISAN JURNAL ILMIAH
}

\section{FRANSISKUS IRWAN WIDJAJA ${ }^{1}$}

STT Real Batam dan Mitra Bestari

Irwan.fiw@sttrealbatam.ac.id

$\mathbf{P}$ ENGALAMAN dan pengamatan di ladang misi adalah informasi yang sangat menarik untuk diteliti. Di antaranya pelayanan gereja, komunitas sel, buah pelayanan, masyarakat, tantangan-tantangan yang di hadapi dan lain sebagainya.

Kegiatan misi di lokus misi, penanaman gereja, pekabaran Injil, tidak terlepas dari strategi etnografi yang akan mempermudah pelayanan lintas budaya. Pelayanan lintas budaya tidak terlepas dari kontekstualisasi. Kurangnya informasi di lokus misi akan

\footnotetext{
${ }^{1}$ Ketua Sekolah STT Real Batam, mengajar mata kuliah Missiologi, Penanaman Gereja dan Suku terabaikan serta Christian's Leadership. Menulis artikel di berbagai jurnal nasional dan internasional. Karyanya dapat dilihat di Google Scholar (ID Google Scholar: mo6gT7cAAAAJ ). Sudah menulis beberapa buku di antaranya: Misiologi Antara Teori, Fakta dan Pengalaman, Misi dan Pluralitas Keyakinan di Indonesia. Aktif duduk di berbagai organisasi dan jaringan misi nasional dan international, dan juga aktif memberi workshop penanaman gereja, pelatihan kepemimpinan dan training pelayanan lainnya.
} 
menyebabkan munculnya kendala-kendala yang berakibat pada gagalanya pecapaian tujuan misi.

Penekanan di bidang tertentu dan menemukan metode pendekatan yang tepat untuk suatu ladang misi dan laporannya adalah sangat menarik untuk di tulis sebagai bahan journal. Pengalaman di lapangan melalui apa yang dilihat, apa yang didengar dan apa yang dirasakan dapat di verifikasi melalui pengukuran yang dapat di pelajari dan di catat untuk diolah dan dapat digunakan baik oleh yang melakukan maupun oleh praktisi yang mempunyai panggilan yang sama di ladang tersebut. Pengamatan dan penelitian biasa di lakukan dengan pertanyaan pertanyaan tentang budaya, bahasa dan geografi. Hasil pengamatan dan penelitian yang dituangkan dalam bentuk etnorafi, yang menurut Novenanto (2013) etnografi di sederhanakan sebagai tulisan tentang menghadirkan yang sesuatu yang spesifik untuk menjelaskan yang umum Novenanto, Anton. "Menulis Etnografi." GapuraUB.

Etnografi akan berguna bagi pemerintah untuk program sosial atau sejenisnya, berguna bagi bisnis marketing dalam memasarkan produk dan sangat efektif bagi pekerjaan misi dalam penanaman gereja.

Paper ini memberikan wawasan kepada pembaca untuk menyusun paper ilmiah dari kegiatan dan laporan misi. Hal-hal apa saja yang dilaporkan dan bagaimana menyusunnya.

\section{METODE}

Metode sederhana yang digunakan dalam melakukan penelitian dan pengamatan yaitu mempelajari manusia di suatu tempat tertentu melalui kehidupan normal sehari-hari (regular life), dalam hal ini, yang perlu dilaporkan adalah kehidupan mereka bukan hanya di lihat dari luar tetapi se-olah olah kita masuk kedalam kehidupan mereka. Implementasi metode untuk penulisan ini diambil dari studi kualitatif, dengan penjelasan dari studi kepustakaan (qualitative study using descriptive literature) dan dipadukan dengan pengalaman di lapangan. Data lapangan yang di 
ambil termasuk observasi di lapangan, obervasi ladang misi termasuk wawancara perseorangan, data-data umum dan data spesifik dari suatu daerah tertentu. Dan data-data tersebut tidak terlepas dari studi yang juga merupakan bagian dari penelitian ethnografi. Pengamatan langsung (Direct observations) di lapangan adalah sumber penting pendataan. Studi kasus terdahulu di ladang misi merupakan sumber otentik yang dapat di jadikan bahan rujukan (Kualitatif research based on literature and case studies)

Dalam dunia misi, penggunaan etnografi bisa di mulai dengan pemetaan suatu daerah tertentu sebelum penjangkauan. Pembagian wilayah kerja, target sasaran wilayah biasa dibagi sebagai berikut:

1) Geografi: di mana mereka tinggal dan mengapa mereka tinggal di sana

2) Demografi: berapa jumlah mereka

3) Ethnis: suku/kaum ini terhubung dengan kelompok apa?

4) Linguistik: bahasa, bagaimana mereka berkomunikasi, cara mereka menanggapi informasi

5) Sosial: bagaimana mereka berinteraksi/berhubungan dengan kelompok sendiri dan juga dunia luar?

6) Ekonomi: bagaimana mereka menggunakan uang, menghargai hasil kerja, tingkat usaha memakmurkan keluarga

7) Keluarga: bagaimana struktur di keluarga? Patrilineal atau matrilineal, fungsi orang tua di keluarga berjalan dengan baik. Mendidik menghormati orang yang di tuai. Ikatan kerabat kekeluargaan.

8) Worldview: apa yang paling di hargai dalam hidup mereka (value) dan apa yang mereka percaya (believe)

9) Struktur Komunitas, siapa yang bisaa memimpin dan beri pengaruh, bagaimana susunan nya struktur nya, system pembatasan dan pengambil keputusan

\section{PEMBAHASAN}

Misi Amanat Agung yang banyak dijalankan gereja Tuhan adalah penjangkauan dan penanaman gereja (Church Planting) yang mana kegiatan misi tersebut menjadi program gereja. Sebenarnya misi 
adalah kegiatan yang holistik yang dapat dipelajari dalam studi yang di sebut misiologi. Misiologi (Widjaja, 2018, hal. 23) adalah studi tentang Tuhan (Teologi), pengalaman dengan Tuhan (experience with God), berjalan dengan kebenaran-Nya (Yoh. 3:16), dimana antropologi (studi tentang manusia dan budaya) dan sejarah dalam masa tertentu terlibat di dalamnya. "Perspektif antropologi dalam konteks pendekatan penelitian sosial dapat dilihat untuk memahami budaya di mana konteks budaya menjadi titik kontak" (Howell \& Paris, 201l, hal. 4). Howell dan Paris (Howell \&\& Paris, 2011, hal. 4) juga mengatakan bahwa "wilayah kerja dari etnografi dalah tanda untuk metode penelitian antropologi". Bagi Howell dan Paris, apabila "pendekatan dalam perspektif antropolgi diterapkan maka dapat memahami dunia dengan lebih baik" (Howell \& Paris, 2011, hal. 4). Implikasinya misiologi dalam dunia nyata adalah dalam bentuk kegerakan misi, pengutusan, penjangkauan, penanaman gereja atau "church planting". Misi juga tidak terlepas dari studi yang di sebut etnografi.

Menurut Howell dan Paris (Howell \& Paris, 2011, hal. 5), etnografi secara harfiah mempunyai arti catatan kehidupan dan cara hidup atau yang lebih ilmiah Etnografi adalah laporan deskriptif tentang kehidupan sosial dan budaya dalam sistem sosial tertentu berdasarkan pengamatan rinci tentang apa yang sebenarnya dilakukan orang. Howell dan Paris (2011, hal. 5) mengungkapkan bahwa, "etnografi memiliki beberapa sub bidang, yaitu: arkeologi, budaya/sosial, fisika/biologi, dan linguistik". Seperti gambar berikut ini (Howell \& Paris, 2011, hal. 6):

Fig. 1.1. The Four Subfields of Anthropology

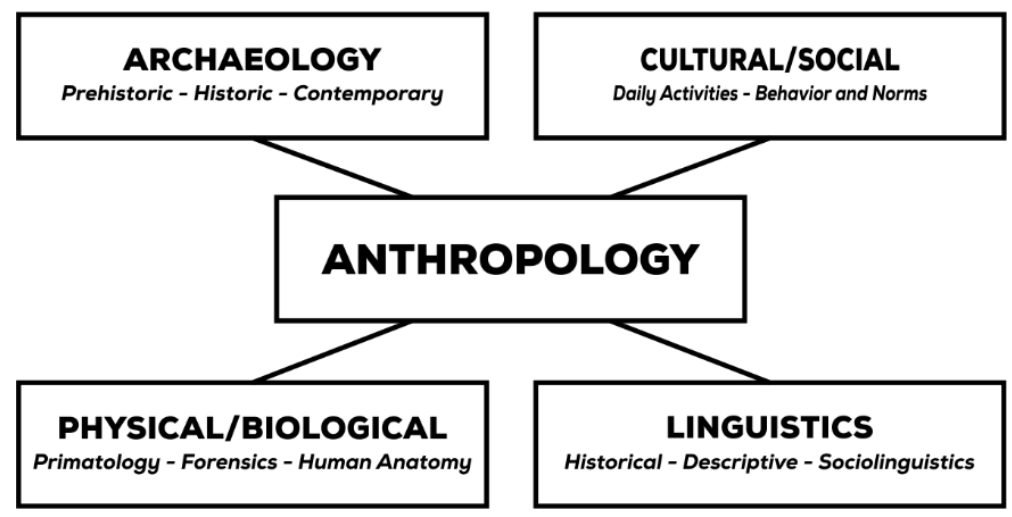


Dalam konteks misiologi, catatan atau laporan misi berkaitan dengan sub bidang etnologi dimaksud.

Seperti definisi di atas, maka etnografi merupakan deskripsi tentang orang dan cara hidupnya. Ini adalah metode penelitian yang sering digunakan oleh sosiolog ketika mempelajari kelompok, organisasi, dan komunitas yang merupakan bagian dari masyarakat kompleks yang lebih besar, seperti kultus agama, lingkungan etnik, atau wilayah geografi tertentu, contoh Melayu di Kepulauan Riau, Asmat di distrik Agats Kabupaten Asmat Papua, dan lain sebagainya. Secara tradisional, dapat diartikan sebagai kesimpulan evaluasi tentang kehidupan dan kebudayaan suatu masyarakat atau etnik; menyangkut adat-istiadat, kebiasaan bagaimana mereka memandang keluarga, hukum, organisasi, agama, keuangan, ilmu pengetahuan, seni, bahasa. Menurut Koentjaraningrat (Metode Penelitian Masyarakat, 1989, hal. 1), pengelanan Barat dalam perjalanan mencari rempah rempah mereka mencatat semua fenomena menarik yang dijumpai selama perjalanannya, termasuk adat istiadat, struktur masyarakat, bahasa dan ciri-ciri fisik dari suku-suku bangsa yang di jumpai".

Etnografi adalah sumber yang potensial untuk penulisan jurnal ilmiah menyangkut profil tentang cara orang-orang dalam budaya tertentu hidup, bertindak, melakukan pekerjaan, dan berhubungan. Etnografi merupakan peta pandangan dan hubungan sosial, agama, ekonomi dan politik suatu budaya (Spradley, 2016, hal. 13). Mempelajari etnografi adalah dasar yang paling sederhana bagi setiap orang misi lapangan untuk masuk dan penetrasi dalam suatu daerah penugasan untuk menemukan orang damai. Orang damai adalah orang yang di siapkan Tuhan, orang yang di pakai sebagai batu lancatan untuk penjangkauan ke suatu kelompok ethne dalam rangka memberitakan kabar baik (Widjaja, 2018, hal. 69)

Konsep etnografi telah dikembangkan dalam antropologi sosial. Sebagian besar studi antropologis mengharuskan kita mengajukan serangkaian pertanyaan kepada anggota budaya untuk memastikan bahwa kita memahami perspektif mereka tentang budaya mereka dan alasan perilaku mereka. Menurut Kraft (Anthropology of Charles or Christian Witness, 1996, hal. 469), situasi yang ideal 
adalah membuat pemimpin masyarakat menjawab pertanyaan, tetapi dalam studi budaya yang lebih spesifik mungkin memerlukan pertanyaan yang harus dijawab oleh orang-orang tertentu yang di pelajari. Analisis penelitian yang di lakukan dan ditulis sesuai data yang di kumpulkan; dapat menggunakan pengalaman, pendapat, pengamatan dan kuesioner untuk menganalisis apa yang dipelajari selama studi.

Melakukan etnografi selalu mengarah pada kesadaran mendalam bahwa sistem makna budaya tertentu sangat kaya hampir tidak ada habisnya. Dalam proses pengumpulan data, seseorang menemukan simpanan pengetahuan tersembunyi yang diperoleh selama proses penelitian. Sebelum menulis laporan dan pengamatan dalam bentuk tulisan etnografi, terlebih dulu harus membaca etnografi lainnya. Perlu dipahami pola-pola budaya yang diamati, mencatat pesanpesan dalam perilaku budaya, artefak, dan pengetahuan. Semakin kita memahami dan mencerna sistem makna budaya yang beroperasi dalam situasi sosial yang kita pelajari, semakin efektif laporan yang akan di buat.

Mengkomunikasikan makna budaya yang di temukan yang mungkin pelaku tidak terbiasa dengan budaya itu. Ini berarti bahwa setiap utusan misi harus mengembangkan keterampilan berkomunikasi dengan orang tempatan sebagaimana yang di infokan Spradley (The Ethnographic Interview , 2016, hal. 58).

Pada langkah ini, dijelaskan secara singkat sifat penulisan etnografi sebagai bagian dari proses untuk laporan Journal. Tulisan yang merupakan tulisan pembanding untuk menentukan pandangan atau "worldview" yang mana Wolters (Wolters, 2005, hal. 2) menjelaskan sebagai kerangka menyeluruh dari kepercayaan dasar seseorang tentang segala hal. Dalam tulisan kesimpulan laporan pada akhirnya akan di buat perbandingan pandangan khusus suatu orang dan membandingkannya dengan pandangan dunia orang lain dan pandangan dunia Kristen. Laporan data juga mengidentifikasi masalah-masalah utama yang akan dihadapi seorang individu dalam situasi lintas budaya dan membuat daftar hambatan dan jembatan yang harus diatasi jika kekristenan ingin memiliki kesempatan untuk mempengaruhi pandangan dunia tempatan. 
Pelaporan sebagai dasar untuk menggabungkan pandangan dunia worldview dan kebenaran Alkitab. Selain itu laporan dan kesimpulan memberi kesempatan individu untuk mengetahui di mana memposisikan orang-orang pada skala pembelajaran dan pada skala penerimaan Injil sebagai bagian dari proses penjangkauan.

\section{Langkah langkah Lapangan:}

Pengumpulan data etnografi yang sederhana untuk membuat laporan dan menjadikan tulisan, perlu di perhatikan waktu dan tempat. Langkah langkah ini menjadi pertimbangan yang di lakukan team survei atau peneliti:

1. Teliti setiap studi antropologi yang tersedia untuk menemukan wawancara etnografi lengkap, profil orang atau pandangan dunia yang baru dan dapat diandalkan. Jika penelitian telah dilakukan, duplikasi pekerjaan tidak diperlukan.

2. Gambarlah peta batas-batas geografis masyarakat. Tentukan dan tandai pusat etnografi orang.

3. Kumpulkan informasi demografis tentang orang-orang yang hidup dalam budaya.

3.1 Populasi menurut pria dan wanita. Jika mungkin, populasi orang sesuai dengan kategori usia standar.

3.2 Tingkat populasi meningkat.

3.3 Kepadatan populasi per kilometer persegi atau per mil persegi.

3.4 Tingkat kelahiran kasar dan tingkat kematian kasar.

3.5 Tingkat kematian janin dan bayi.

3.6 Tingkat perkawinan dan perceraian.

3.7 Tingkat migrasi. (laju migrasi masuk dan keluar dari populasi)

3.8 Status pernikahan: Lajang, Menikah, Bercerai, Terpisah, dan Duda.

3.9 Status pendidikan: Persen populasi yang mendaftar di sekolah dasar, persen populasi yang melampaui nilai sekolah dasar hingga tingkat menengah, pendaftaran di 
tingkat sekolah dasar, pendaftaran di pendidikan lanjutan di luar tingkat menengah berdasarkan kategori jika memungkinkan.

3.10 Status melek huruf: Persen yang tidak melek huruf (buta huruf atau pra melek huruf), Persen buta huruf fungsional, Persen semi melek huruf, dan Persen Melek huruf (Melek huruf adalah seseorang yang secara fungsional melek ketika ia memperoleh pengetahuan dan keterampilan dalam membaca dan menulis) yang memungkinkannya untuk terlibat secara efektif dalam semua kegiatan di mana literasi biasanya diasumsikan dalam budaya atau kelompoknya.

3.ll Data linguistik. Bahasa atau versi dialek bahasa di antara populasi.

3.12 Data agama menurut setiap kelompok agama yang ada

4. Melakukan studi pandangan dunia atau studi etnografi tentang orang-orang. Ini adalah studi deskriptif tentang budaya tertentu, pengamatan mendalam dan proses pengumpulan informasi yang menghasilkan analisis budaya. Pilihan informan dan penerjemah sangat penting. Penelitian harus representatif.

5. Buat profil orang, monograf etnografi atau dokumen pandangan dunia.

6. Sebagai bagian dari proses konstruksi pandangan dunia, orang ingin membandingkan etnografi orang atau pandangan dunia dengan orang Kristen, pandangan Alkitab tentang kehidupan Kristen. Persiapkan daftar kesamaan dan hambatan untuk Injil dan gaya hidup Kristen.

7. Kategori umum yang akan dipertimbangkan untuk dimasukkan dalam instrumen etnografi atau pandangan dunia (worldview).

8. Lingkaran kehidupan: kelahiran, penamaan, menyapih, pertunangan, pernikahan, perceraian.

9. Kebiasaan Rumah Tangga: makanan, kebersihan pribadi, pembersihan 
10. Kehidupan publik: Bahasa, kesediaan, hubungan, Instruksi untuk Anak-anak, tabu, budaya, keyakinan, ketakutan, kekerabatan

11. Struktur Budaya: perumahan, desain arsitektur, kebiasaan dan aturan berpakaian

12. Bentuk Ritual: Doa, sesembahan, sumpah, ramalan, nasib orang mati, roh, orang suci/nabi, kuil, objek suci.

\section{Proses dan Instrumen Pengembangan mengetahui Worldview}

Instrumen ini dirancang untuk digunakan selama wawancara etnografi untuk mengumpulkan informasi membangun profil masyarakat, pandangan budaya. instrumen ini digunakan dalam mengumpulkan data data konkrit dalam budaya yang sedang dipelajari. Yang terbaik adalah penelitian atau survei dilakukan di antara orang-orang yang tinggal di pusat etnografi budaya. Hindari mensurvei hanya orang pinggiran, atau orang yang tidak lagi hidup dalam batas-batas budaya yang dipelajari. Individu yang diwawancarai harus seperti mayoritas orang dalam budaya. Spraedley (The Ethnographic Interview , 2016, hal. 103) menjelaskan beberapa poin pertanyaan dan di modifikasi penulis sebagai berikut:

1. Struktur Keluarga.

1.l Apakah keluarga itu monogami atau poligami? Jelaskan karakteristik dan kondisi.

1.2 Apakah keluarga matriarkal atau patriarkal? Jelaskan "kepala rumah."

1.3 Apa garis otoritas dalam keluarga? Siapa yang membuat keputusan bagaimana, kapan dan mengapa?

1.4 Apa harapan dan aturan untuk mendapatkan izin?

1.5 Apa harapan dan aturan untuk mendapatkan pengampunan?

1.6 Apa peran dan hubungan konsekuen antara anggota keluarga? Termasuk suami, istri, anak, kerabat. Apa perbedaan di tingkat yang berbeda di masyarakat dan untuk 
usia yang berbeda? Siapa yang bertanggung jawab untuk siapa, kapan dan bagaimana?

1.7 Identifikasi garis kekerabatan dan pola keluarga besar.

1.8 Bagaimana keluarga mendukung diri mereka sendiri dalam budaya ini? Apa cara dukungan tradisional dan non tradisional?

1.9 Bagaimana struktur keluarga berubah akibat kematian, perkawinan, perpisahan, ketidakmampuan, ketidakmampuan, atau perubahan signifikan lainnya?

1.10 Bagaimana warisan keluarga diturunkan dari satu generasi ke generasi berikutnya?

1.11 Apakah keluarga memiliki totem? Apa yang khas dan bagaimana mereka digunakan?

1.12 Bagaimana berita otentik disampaikan dalam keluarga?

1.13 Apa aturan pewarisannya?

1.14 Apa peran dan aturan seksual dan perkawinan dalam keluarga? Apa ritus dan aturan pernikahan?

1.15 Bagaimana keluhan diselesaikan dalam keluarga? Apa aturan tentang penganiayaan, perpisahan, perceraian, atau wanita simpanan?

1.16 Apa praktik dan tradisi pengasuhan anak?

1.17 Bagaimana anak-anak memilih panggilan hidup mereka, peran mereka dalam masyarakat?

1.18 Apa hari atau acara khusus untuk keluarga?

1.19 Bagaimana keluarga berubah?

1.20 Bagaimana seorang individu membela diri dalam keluarga?

2. Struktur Sosial.

2.1 Bagaimana masyarakat suatu komunitas diorganisasikan? Apa sajakah ciri khas masyarakat yang homogen dan heterogen?

2.2 Bagaimana hubungan keluarga yang berbeda satu sama lain? Bagaimana keluarga bertemu keluarga lain di komunitas? Apa aturan rapat dan berteman?

2.3 Bagaimana tempat seseorang dalam masyarakat desa atau komunitas ditentukan? Apakah ada sistem kasta atau jenis struktur lain dalam budaya?

2.4 Bagaimana hubungan masyarakat dengan orang asing? Orang asing dari kota lain, ras lain, suku lain, negara lain? 
Apa sikap dan aturan berhubungan?

2.5 Bagaimana real estat ditangani? Apa aturan kepemilikan, penjualan dan pembelian?

2.6 Bagaimana individu menjadi dewasa? Apakah aturan pengakuan dan ritus perjalanan mereka? Pada usia berapa mereka muncul? Bagaimana keadaan kemunculan mereka?

2.7 Hak-hak apa yang dimiliki individu di dalam komunitas, di dalam masyarakat? Apa hak keluarga? Hak-hak apa yang dimiliki klan dalam masyarakat? Hak-hak apa yang dimiliki pria? Hak apa yang dimiliki perempuan?

2.8 Bagaimana para pemimpin dipilih? Siapa yang berhak? Kapan mereka memenuhi syarat?

2.8.1 Dalam kondisi apa dan dengan aturan apa mereka dipilih?

2.8.2 Bagaimana para pemimpin diakui oleh masyarakat, oleh masyarakat?

2.8.3 Bagaimana para pemimpin diubah?

2.8.4 Apa hak dan tanggung jawab pemimpin?

2.8.5 Bagaimana para pemimpin kehilangan hak untuk memimpin?

2.8.6 Bagaimana individu berhubungan dengan pemimpin mereka?

2.8.7 Bagaimana para pemimpin berhubungan dengan para pemimpin lain dalam budaya?

2.9 Apa nilai-nilai dasar dalam masyarakat yang memberikan kohesi dan keamanan?

2.10 Apa tabu dasar dalam masyarakat?

2.11 Apa tradisi umum dalam masyarakat?

2.12 Apa saja bentuk seni atau seni yang dihargai di masyarakat?

2.13 Apa preferensi belajar orang-orang? Apakah sebagian besar orang komunikator lisan atau sebagian besar komunikator melek huruf?

2.14 Bagaimana komunikasi dilakukan? Dengan siapa? Apa aturannya?

2.15 Apa saluran untuk berita? Siapa yang tahan berita? Bagaimana? Kapan dan bagaimana berita diakui sebagai resmi dan otentik? Adakah tempat, waktu, atau bentuk seni tertentu di mana kebenaran atau berita autentik dan 
resmi diberikan kepada komunitas?

2.16 Bagaimana individu "dididik" tentang aturan-aturan dalam komunitas, masyarakat dan budaya?

2.17 Bagaimana individu dididik? Apakah ada sistem pendidikan formal seperti sekolah? Apakah ini untuk semua orang? Apakah ini meresap? Apakah itu dihormati? Apakah ini efektif?

2.18 Jelaskan tangga hormat kejuruan dalam masyarakat? Apa levelnya?

2.19 Jelaskan bagaimana masyarakat memandang pernikahan? Apa aturan dalam masyarakat tentang pacaran, pertunangan, pernikahan, dan perceraian?

2.20 Apa aturan berpakaian di masyarakat?

2.21 Jelaskan hukum dan ketertiban dalam masyarakat? Struktur? Proses?

2.22 Jelaskan perawatan medis dalam masyarakat? Mengetik? Struktur? Praktisi?

3. Struktur Agama.

3.1 Jelaskan sistem atau sistem keagamaan yang dominan di masyarakat?

3.2 Apakah agama itu mengekspresikan kepercayaan pada dewa atau dewa? Beri nama \& jelaskan. Jika mereka memiliki kepercayaan pluralistik pada dewa, apa hubungan antara para dewa?

3.3 Bagan dan gambarkan dunia roh orang (makhluk, tempat, dan status).

3.4 Di mana kekuasaan dan otoritas berada dalam agama? Apa sumber otoritas dan kekuasaan? Apakah orang-orang percaya pada keajaiban dan sihir? Apakah mereka percaya takhayul?

3.5 Bagian apa yang dimainkan oleh leluhur yang telah meninggal dalam agama? Apakah ada interaksi antara yang hidup dan yang mati?

3.6 Apa dokumen utama agama itu?

3.7 Apa ritus dan acara keagamaan yang umum?

3.8 Apa pandangan mereka tentang Ketuhanan dan posisi Tuhan?

3.9 Apa ciri-ciri Tuhan dalam agama mereka? 
3.10 Apa keyakinan dasar itu? Tentang Tuhan Tentang kebaikan dan kejahatan? Tentang hidup? Tentang sumber kehidupan \& ciptaan? Tentang kematian? Tentang manusia? Tentang roh? Tentang salah, dosa dan kesalahan? Tentang keabadian? Tentang keselamatan? Tentang kehidupan setelah mati? Tentang penyakit? Tentang mengamankan orang yang insaf atau penganut? Tentang penyimpangan dari agama? Tentang wanita.

3.1l Bagaimana seseorang berhubungan dengan agama? Apakah pilihan pribadi dihormati?

3.12 Bagaimana agama melibatkan masyarakat? Bagaimana hubungannya dengan masyarakat? Bagaimana hubungan masyarakat dengan agama? Apa posisi agama dalam masyarakat?

3.13 Bagaimana agama melibatkan keluarga?

3.14 Bagaimana agama memandang orang asing?

3.15 Bagaimana agama memandang agama lain?

3.16 Siapa pemimpin agama? Bagaimana mereka dipilih? Dalam kondisi apa dan dengan aturan apa? Bagaimana pemimpin agama diakui dan diberi sanksi?

3.17 Apakah agama mengajar dan apakah orang percaya menggunakan jimat, jimat dan masuk ke dalam ritus magis?

3.18 Apa hubungan antara dunia yang terlihat dan dunia yang tidak terlihat?

3.19 Apakah agama itu animistis atau bercampur dengan animisme?

4. Struktur Ekonomi.

4.1 Apakah struktur ekonomi masyarakat agraris, industri atau campuran?

4.2 Apa pendorong utama perekonomian? Kapitalisme, sosialisme atau lainnya? Jelaskan ekonomi.

4.3 Apa kategori dan divisi ekonomi dan kejuruan utama dalam perekonomian?

4.4 Apa pola struktural dalam masyarakat?

4.5 Bagaimana harga ditentukan? Apa pengaruh utama pada harga?

4.6 Siapa yang mengendalikan aliran uang? 
4.7 Siapa yang mengendalikan lembaga keuangan? Apakah ada proses keuangan pribadi yang sekuat atau berpengaruh seperti lembaga publik?

4.8 Jelaskan kelas tradisional dalam perekonomian? Bawah / Tengah / Atas

4.9 Apakah budaya barter ada? Apakah itu mendominasi? Apakah ini penting?

4.10 Bagaimana hubungan ekonomi dengan negara lain?

4.1l Bagaimana jaminan sosial disediakan? Dalam struktur keluarga, sosial atau pemerintahan?

\section{KESIMPULAN}

Tulisan ini berisi proses untuk mengembangkan dan instrumen model untuk digunakan dalam membangun laporan lapangan etnografi sebagai bahan tulis untu jurnal. Laporan misi Ini dirancang untuk digunakan untuk penanaman gereja dengan fokus yang biasanya diidentifikasi dengan budaya, bahasa dan geografi. Pertanyaan-pertanyaan yang di buat menggambarkan tentang kebutuhan yang dibutuhkan dalam kehidupan suatu masyarakat tertentu sehingga mempermudah mengidentifikasi, menggambarkan pandangan (WV) seseorang dan mejembatani (bridging) penyampaian kabar bagik. Selain sebagai laporan misi, laporan laporan tersebut juga bias di pakai untuk menulis jurnal. Namun, dalam sejumlah situasi, pertanyaan lain perlu dipertimbangkan dan beberapa dari yang sudah ada disesuaikan. Dalam situasi seperti itu, penelitian dan pengamatan yang lebih dari sekadar kuesioner aktual yang akan digunakan. Dalam situasi seperti itu, yang di amati adalah profil tentang cara orang-orang dalam budaya tertentu hidup, bertindak, melakukan pekerjaan, dan berhubungan, suatu peta secara keseluruhan mengenai pandangan dan hubungan sosial, agama, ekonomi dan politik suatu budaya.

Belajar memahami pandangan dunia (worldview) dari dalam budaya yang di amati melaui persahabatan yang di bangun akan menghasilkan informasi untuk church planting dan pelayanan lainnya dan juga untuk penulisan jurnal yang mencakup dimensi kognitif, ekspresif \& evaluative. 


\section{REFERENSI}

Howell, B. M., \& Paris, J. W. (2011). Introducing Cultural Anthropology: A Christian Perspective. Michigan: Grand Rapids.

Koentjaraningrat. (1989). Metode Penelitian Masyarakat. Jakarta: Gramedia.

Kraft, C. H. (1996). Anthropology of Charles or Christian Witness. New York: Orbis Books.

Spradley, J. P. (2016). The Ethnographic Interview. Illinois: Waveland Press.

Widjaja, F. I. (2018). Misiologi: Antara Teori, Fakta dan Pengalaman . Yogykarta: Andi Offset.

Wolters, A. M. (2005). Creation Regained: Biblical Basics for a Reformational Worldview. Cambridge: Eerdams. 